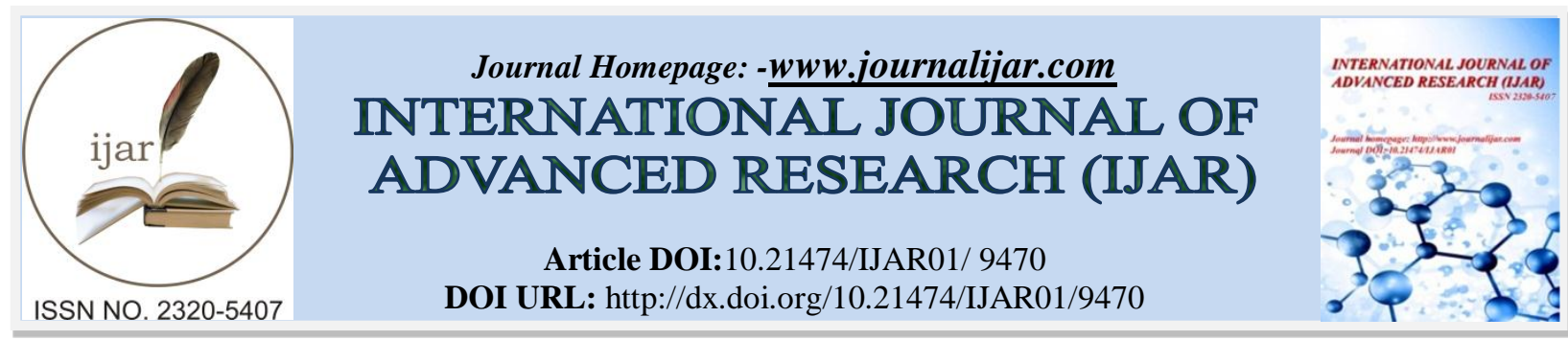

RESEARCH ARTICLE

\title{
WATERSHED MODELING FOR WATER RESOURCE MANAGEMENT IN TWO BASINS OF NORTHWESTERN COASTAL ZONE, EGYPT.
}

\author{
Abdel Ghaffar, M.K., Shoman M. M., El Ghonamey, Y. K. and Abdellatif, A. D. \\ Remote Sensing \& GIS Unit; Soils, Water and Environmental Research Institute; ARC.
}

\section{Manuscript Info}

\section{Manuscript History}

Received: 02 June 2019

Final Accepted: 04 July 2019

Published: August 2019

Key words:-

WMS Modeling, DEM, RWH, CN, NWCZ-Egypt, Morphometric parameters.

\section{Abstract}

Water resources in the coastal area of Egypt are very limited in magnitude as they originate mainly from the rainfall of the winter season. This water scarcity problem is the major constraint for the developmental activities in the area. Runoff Water Harvesting (RWH) is one of the most effective solutions to overcome this problem.

The main objective of this research is to use the watershed modeling system (WMS) approach involving the integration of Digital Elevation Model (DEM), meteorological data, land use/land cover, soil type and hydrological model to assess the potentiality of two important basins (Umm Ashtan and Umm El-Rakham) near the city of Mersa Matrouh for water resources management and agricultural development activities. The study aimed also to predict annual peak flow and runoff water volume, as well as the 100-, 50-, 25-, 10-, and 5-year return periods.

Results indicated that, the study area includes eight landform units namely: coastal plain, sloping area, escarpment, coarse valley inner, coarse valley outer, low piedmont, moderately high piedmont and high piedmont. Results showed also that Umm Ashtan basin is characterized by larger basin area $\left(105.8 \mathrm{~km}^{2}\right)$, basin length of $34.3 \mathrm{~km}$, perimeter of $119.4 \mathrm{~km}$, and gentle slope $(0.024 \mathrm{~m} / \mathrm{m})$ as compared with Umm ElRakham basin. Three types of land use/land cover in the studied basins were identified, namely: agricultural land, barren land and urban. The land use/land cover types represent $16.4,83.59$ and $0.21 \%$ of Um Ashatan basin and 34.0, 64.0 and $2.0 \%$ of Um Al-Rakham basin, respectively. The Curve Number $(\mathrm{CN})$ average values are 73.8 and 76.15 for of Umm Ashtan and Umm El-Rakham basins, respectively. The annual runoff water volumes are $66150.0 \mathrm{~m}^{3}$ and $49896.7 \mathrm{~m}^{3}$ for the first and second basins, respectively. However, the annual infiltration volumes are $41398.0 \mathrm{~m}^{3}$ and $26450.6 \mathrm{~m}^{3}$ for the first and second basins, respectively. The peak flow of the 100-, 50-, 25-, 10-, and 5-year return periods are 73.53, 49.28, 30.68, 13.58 and $5.46 \mathrm{~m}^{3} / \mathrm{s}$ for the first basin and 75.82, 49.96, 30.41, 12.82 and $4.77 \mathrm{~m}^{3} / \mathrm{s}$ for the second basin, respectively. The Runoff volume of the 100-, 50-, 25-, $10-$, and 5-year return periods are $3667.25 \times 10^{3}, 2490.05 \times 10^{3}$, $1577.16 \times 10^{3}, 721.47 \times 10^{3}$ and $300.63 \times 10^{3} \mathrm{~m}^{3}$ for the first basin and $4618.33 \times 10^{3}, 3071.74 \times 10^{3}, 1891.25 \times 10^{3}, 813.18 \times 10^{3}$ and $306.49 \times 10^{3}$ $\mathrm{m}^{3}$ for the second basin, respectively. 
The two basins (Umm Ashtan and Umm El-Rakham) can be recommended to have priority for rainwater harvesting with agriculture potential benefits within the Northwestern coast of Egypt.

Copy Right, IJAR, 2019,. All rights reserved.

\section{Introduction:-}

Egypt is one of the countries which lie in the arid zones, characterized by dry climate in most of its regions. However, the northwestern coastal zone (NWCZ) belongs to the subtropical Mediterranean climate with cold and wet winters, hot and dry summers. The NWCZ extends over $350 \mathrm{~km}$ from west of Alexandria to the Libyan border. Human settlements and land use are entirely dependent on rainfall and on various forms on water harvesting (Moustafa, 1994). Annual rainfall is restricted to the winter months and to a narrow $20 \mathrm{~km}$ strip from the coast (Abdel-Kader and FitzSimon, 2002). Rainfall tapers off very rapidly with distance from the coast. Rainfall patterns are extremely erratic, with high fluctuations spatially as well as within and between years. Potentially productive areas in terms of runoff accumulation and soils are concentrated within a small number of wadis and depressions. There are 218 wadis with their watersheds and sub-watersheds in the NWCZ (FAO, 1970). One of the main issues for the sustainable development is to increase the efficiency of runoff water use for human and animal consumption and cultivation, and to minimize soil erosion.

Temporary surface runoff occurs immediately after rainy periods and represents a definite percentage of the rainfall. Water runoff differs from one locality to another depending on some factors such as slope, topography, nature of cap rock, field water capacity and the catchment area. Therefore, water harvesting systems are applied through the construction of soil, cemented and/or stony dykes established between different levels along the streams. In limited areas, supplemental irrigation with shallow well water is used (DRC, 2015).

Runoff is one of the most important hydrologic variables used in most of the water resources applications. Its occurrence and quantity are dependent on the characteristics of rainfall event, i.e. the intensity, duration and distribution. Apart from these rainfall characteristics, there are number of catchment specific factors which have a direct effect on the occurrence and volume of runoff. These factors include soil type, vegetation cover, slope and catchment type.

The Soil Conservation Service Curve Number (SCS-CN) provides an empirical relationship for estimating initial abstraction and runoff as a function of soil type and land-use. Curve Number $(\mathrm{CN})$ is an index developed by the Natural Resource Conservation Service (NRCS) to represent the potential for storm water runoff within a drainage area. The $\mathrm{CN}$ for a drainage basin is estimated using a combination of land use, soil, and antecedent soil moisture condition. There are four hydrologic soil groups: A, B, C and D. Group A have high infiltration rates and group D have low infiltration rates. SCS-CN method is widely used for predicting direct runoff volume for a given rainfall event. This method was originally developed by the US Department of Agriculture, Soil Conservation Service and documented in detail in the National Engineering Handbook, Sect. 4: Hydrology (NEH-4, 1993). Natural Resource Conservation Service Curve Number (NRCS-CN) was chosen for this study since it is useful for ungauged watersheds (El-Hames, 2012).

The Curve Number parameter is dimensionless and varies between 0 (maximum infiltration) and 100 (zero infiltration). Low $\mathrm{CN}$ values mean that the surface of the basin has a high potential to retain water, whereas high values indicate that the rainfall could only be stored to a limited extend (Xiao et al., 2011).

In hydrological processes, land use is used to describe how people use an area of land, including a variety of human uses such as urban, agriculture, bare soil, forest, pasture, and water body (Rajesh, 2007). Infiltration losses of the soil are related to the land use and differ greatly between forested, agricultural, and urban areas (USACE, 1994). The peak flow refers to the maximum flow for a particular stream during a storm event. This determination plays a crucial role in hydrology. It has a significant value in many hydrological applications such as the design of hydraulic structures (i.e. small dam, culverts, and bridges) and helps in understanding the available water resources for water resources management (El-Hames, 2012).

The main objective of this research is to use the watershed modeling system (WMS) approach involving the integration of Digital Elevation Model (DEM), meteorological data, land use/land cover, soil type and hydrological 
model to assess the potentiality of two important basins (Umm Ashtan and Umm El-Rakham) near the city of Mersa Matrouh for water resources management and agricultural development activities. The study aimed also to predict annual peak flow and runoff water volume, as well as the 100-, 50-, 25-, 10-, and 5-year return periods.

\section{Materials and Methods: -}

\section{Location of the study area:}

The study area is located in the Northwestern Coastal Zone (NWCZ) of Egypt between the longitudes $26^{\circ} 57^{\prime} 00^{\prime \prime}$ to $27^{\circ} 05^{\prime} 00^{\prime \prime} \mathrm{E}$ and the latitude $31^{\circ} 10^{\prime} 45^{\prime \prime}$ to $31^{\circ} 24^{\prime} 30^{\prime \prime} \mathrm{N}$ with an area of $177.18 \mathrm{~km}^{2}$. To achieve the objectives of this study, two important basins (Umm Ashtan and Umm El- Rakham) near the city of Mersa Matrouh were chosen (Figure 1). Umm Ashtan and Umm El-Rakham represent the catchment basins of twelve drainage patterns located west of Mersa Matrouh city. They receive appreciable amounts of rainwater during rainy periods and represent optimal sites for rainwater harvesting.

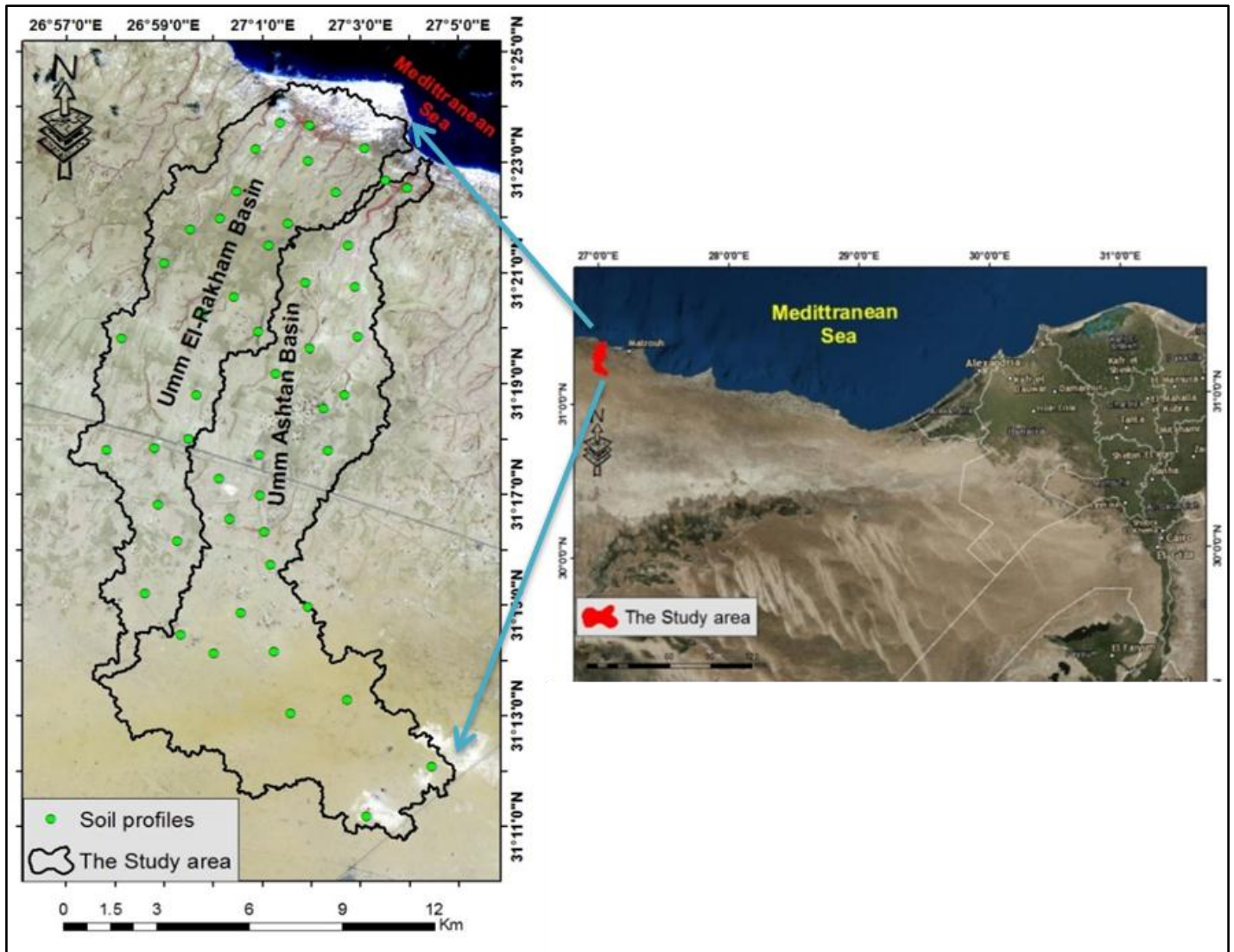

Figure 1:-Location map of the study area in Egypt (to the right); the study basins and soil profiles on subset Planet image (to the left).

\section{Main features of the selected area:}

Lithological features: The area under investigation is dominated by a sedimentary succession ranging from Tertiary period (Middle Miocene) to Quaternary. Middle Miocene sediments are widely spread in the tableland. Quaternary deposits are differentiated into Pleistocene and Holocene Formations. They have wide distribution and constitute the bulk of the coastal plain (El-Shazely et. al., 1975). For details, area between the present shoreline and Libyan plateau is mostly constituted of calcareous Pliocene and Pleistocene Formations and covered by Recent deposits (Shata, 1971).

\section{Ecological features:}

Many natural plants were recorded in wadis and their surrounding areas. These plants differ in type, economical use and palatability for animals. They include perianal and annual species as well as various range aromatic and medicinal types (DRC, 2015). 


\section{Climatological features:}

The NWCZ is characterized by a Mediterranean climate. According to (Verheye \& de la Rose, 2005) the main characteristic of the Mediterranean climate has two well defined seasons in the year, winter rain period coinciding with low temperatures, while summers are hot and almost completely dry. According to metrological data of Matrouh station from 2001 to 2015, obtained from Central Laboratory for Agriculture Climate (Table 1), the study area is classified as arid with mild winter and warm summer (UNESCO, 1977). Data showed that means of annual rainfall ranged from $263.13 \mathrm{~mm}$ during 2007 to $60.96 \mathrm{~mm}$ during 2014 with an average of $127.2 \mathrm{~mm}$ (increasing from West to East and from South to North) (Figure 2). The rain comes in outbursts over short period of time. The main rainy season is between October and March and the rest of the year (April to September) is almost dry (Sayed, 2013). Mean annual temperature was $20.38^{\circ} \mathrm{C}$, and the maximum annual temperature ranged from $25.9^{\circ} \mathrm{C}$ in 2010 to $24.13{ }^{\circ} \mathrm{C}$ in 2005 , while the minimum annual temperature ranged from $15.55^{\circ} \mathrm{C}$ in 2007 to $16.48^{\circ} \mathrm{C}$ in 2010 . Average annual humidity ranged from $68.47 \%$ in 2015 to $62.34 \%$ in 2005 . Prevailing winds mainly directed northwest in the most of year months. Mean wind speed varies from (15.1 to $20.89 \mathrm{~km} / \mathrm{h})$. The lowest values of evaporation $(2.7$ $\mathrm{mm} /$ day) are recorded in January, while the highest value is recorded in July and June (5.9 mm/day) (Sayed, 2013).

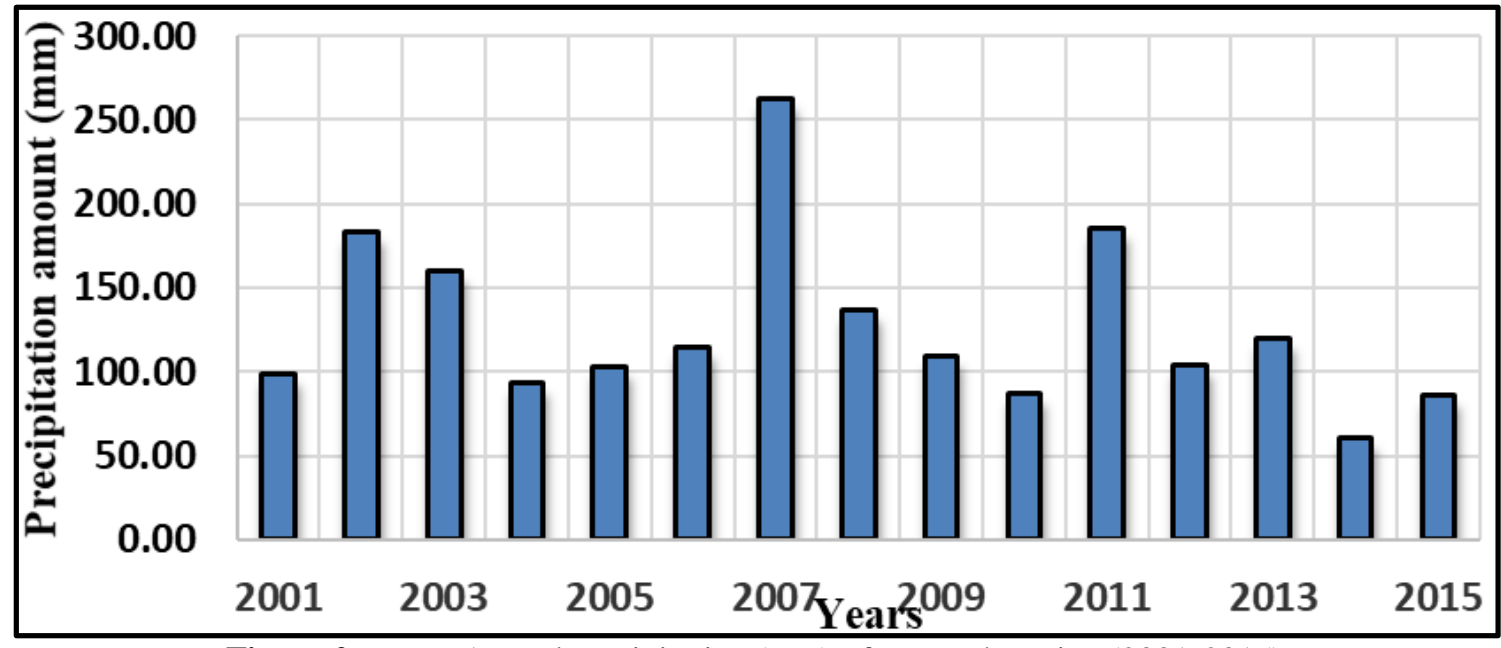

Figure 2:-Mean Annual precipitation (mm) of Matrouh station (2001-2015).

Table 1: Climatological normal at Matrouh station (2001-2015)*

\begin{tabular}{|c|c|c|c|c|c|c|c|c|c|c|c|c|c|c|}
\hline Year & Tmean. & Tmax. & Tmin. & SLP & RH & PP & VV & V & VM & VG & RA & SN & TS & FG \\
\hline $\mathbf{2 0 0 1}$ & 20.34 & 24.98 & 15.55 & 1015.6 & 66.25 & 98.3 & 9.97 & 17.7 & 28.3 & 0 & 1.75 & 0 & 0 & 0.42 \\
\hline $\mathbf{2 0 0 2}$ & 20.36 & 24.81 & 15.7 & 1015.74 & 67.03 & 183.1 & 10.06 & 15.1 & 25.61 & 0 & 2.25 & 0.08 & 0.08 & 0.17 \\
\hline $\mathbf{2 0 0 3}$ & 20.14 & 24.72 & 15.57 & 1014.92 & 66.4 & 160.53 & 9.81 & 15.93 & 26.79 & 0 & 3.17 & 0 & 0 & 0.25 \\
\hline $\mathbf{2 0 0 4}$ & 20.07 & 24.54 & 15.55 & 1015.82 & 62.63 & 93.98 & 10.11 & 16.53 & 26.55 & 0 & 1.75 & 0 & 0 & 0.17 \\
\hline $\mathbf{2 0 0 5}$ & 20.03 & 24.13 & 15.94 & 1015.88 & 62.34 & 103.37 & 10.14 & 18.27 & 29.3 & 0 & 2.17 & 0 & 0 & 0.33 \\
\hline $\mathbf{2 0 0 6}$ & 20 & 24.4 & 15.67 & 1015.63 & 65.55 & 114.55 & 9.98 & 19.94 & 31.69 & 0 & 2.58 & 0 & 0.08 & 0.17 \\
\hline $\mathbf{2 0 0 7}$ & 20.17 & 24.48 & 15.75 & 1015.26 & 67.52 & 263.13 & 9.99 & 20.89 & 31.87 & 0 & 2 & 0 & 0 & 0.25 \\
\hline $\mathbf{2 0 0 8}$ & 20.68 & 25.21 & 16.05 & 1015.67 & 65.74 & 137.16 & 9.97 & 16.36 & 26.38 & 0 & 3 & 0 & 0.25 & 0.5 \\
\hline $\mathbf{2 0 0 9}$ & 20.38 & 24.76 & 15.8 & 1014.71 & 63.28 & 109.5 & 9.74 & 15.73 & 25.53 & 0 & 1.42 & 0 & 0.25 & 0.5 \\
\hline $\mathbf{2 0 1 0}$ & 21.13 & 25.9 & 16.48 & 1014.38 & 62.98 & 87.12 & 9.75 & 17.98 & 29.51 & 0 & 0.67 & 0 & 0 & 0.33 \\
\hline $\mathbf{2 0 1 1}$ & 20.03 & 24.42 & 15.59 & 1015.38 & 66.06 & 185.72 & 9.9 & 17.13 & 27.59 & 0 & 2.58 & 0 & 0.08 & 0.33 \\
\hline $\mathbf{2 0 1 2}$ & 20.71 & 25.07 & 16.34 & 1014.55 & 67.11 & 103.62 & 9.87 & 18.83 & 29.62 & 0 & 2 & 0 & 0.08 & 0.08 \\
\hline $\mathbf{2 0 1 3}$ & 20.52 & 25.01 & 16.08 & 1014.92 & 67.48 & 120.39 & 9.61 & 19.95 & 30.49 & 0 & 1.42 & 0 & 0 & 0.25 \\
\hline $\mathbf{2 0 1 4}$ & 20.71 & 25.43 & 16.06 & 1015.5 & 68.2 & 60.96 & 9.48 & 18.3 & 29.23 & 0 & 1.17 & 0 & 0.25 & 0 \\
\hline
\end{tabular}




\begin{tabular}{|c|c|c|c|c|c|c|c|c|c|c|c|c|c|c|}
$\mathbf{2 0 1 5}$ & 20.38 & 25.15 & 15.75 & 1016.23 & 68.47 & 86.37 & 9.63 & 18.47 & 30.39 & 0 & 2.67 & 0 & 0.42 & 0.17 \\
\hline Average & $\mathbf{2 0 . 3 8}$ & $\mathbf{2 4 . 8 7}$ & $\mathbf{1 5 . 8 6}$ & $\mathbf{1 0 1 5 . 3 5}$ & $\mathbf{6 5 . 8}$ & $\mathbf{1 2 7 . 1 9}$ & $\mathbf{9 . 8 7}$ & $\mathbf{1 7 . 8 1}$ & $\mathbf{2 8 . 5 9}$ & $\mathbf{0}$ & $\mathbf{2 . 0 4}$ & $\mathbf{0 . 0 1}$ & $\mathbf{0 . 1}$ & $\mathbf{0 . 2 6}$ \\
\hline
\end{tabular}

*source: Central Laboratory for Agricultural Climate (CLAC, 2015)

\section{Interpretation}

Tmean: Mean temperature $\left({ }^{\circ} \mathrm{C}\right)$

Tmax: Maximum temperature $\left({ }^{\circ} \mathrm{C}\right)$

Tmin: Minimum temperature $\left({ }^{\circ} \mathrm{C}\right)$

SLP: Mean sea level pressure $(\mathrm{hPa})$

RH: Mean humidity (\%)

PP: Precipitation depth (mm)

VV: Mean visibility $(\mathrm{Km})$
V: Mean wind speed $(\mathrm{km} / \mathrm{h})$

VM: Maximum sustained wind speed $(\mathrm{km} / \mathrm{h})$

VG: Maximum wind gust $(\mathrm{km} / \mathrm{h})$

RA: Indicator for occurrence of Rain or Drizzle

SN: Indicator for occurrence of Snow or Ice Pellets

TS: Indicator for occurrence of Thunder

FG: Indicator for occurrence of Fog

\section{Methodology: -}

The following steps were used to conduct this study:

1. Field observations of the study area including land use/land cover, landforms and geology were done.

2. Soil samples from 50 soil profiles located by the Global Positioning System (GPS, Figure 1) were collected for physical and chemical analyses.

3. Laboratory analyses: Soil samples were air dried, crushed and sieved through a $2 \mathrm{~mm}$ sieve. The fine fractions ( $<2 \mathrm{~mm}$ ) were used for physical and chemical analyses. Particle size distribution was determined using the international pipette method (USDA, 2004). Calcium carbonate content was measured using the Collin's Calcimeter method (USDA, 2004). Gypsum was determined by the acetone method (Richards, 1954). Organic matter content was determined according to the method given by Walkley and Black (1947). Soil pH was determined in the soil paste extract using $\mathrm{pH}$ meter and total salinity was expressed as electrical conductivity (ECe dS/m) (USDA, 2004).

4. A Digital elevation model (Figure 3) derived from Sentinel-2A sensor of $12.5 \mathrm{~m}$ resolution as well as geological map; Planet high-resolution visible and an infrared sensor (3 m spatial resolution) acquired in September 2018 and field observations, was used to identify the landforms of the study area in Arc GIS V.10.4.1 software (ESRI, 2014) according to Zinc (1988).

5. Daily rainfall data from Matrouh meteorological station have been used in order to deduce the maximal annual rainfall indispensable data for the estimation of the rainfall intensity for various return periods by using HYFRAN-PLUS software.

6. Curve Number (CN) values were calculated according to Xiaoyong Zhan and Min Lang Huang (2004) by using the land use and soil type maps developed by Arc GIS 10.4.1 software.

7. The watershed and streams were delineated from DEM in WMS 10.0 software, and the geometric (morphometric) watershed characteristics were automatically calculated.

8. The Natural Resources Conservation Service (NRCS) runoff equation was developed to estimate total storm runoff from total storm rainfall (NEH-4, 1993).

9. The HEC-1 model components are used to simulate the rainfall-runoff process as it occurs in an actual river basin. The model components are based on simple mathematical relationships which are intended to represent individual meteorologic, hydrologic and hydraulic processes which comprise the precipitation-runoff process.

10. The WMS and HEC-1 model were applied for the two selected basins in NWCZ. The WMS provides tools for all phases of watershed modeling including automated watershed delineation, morphometric parameter computation, hydraulic parameter computation (e.g. Time of concentration and Lag-Time) and result visualization (EMRL, 2015).

11. The HEC-1 parameters were setup as follows:

1. Precipitation: A precipitation hyetograph is used as the input for all runoff calculations. The precipitation-time distribution was entered with a SCS-24 hours storm type II. The total depth of the rainfall was also given.

2. Loss method: One of several different loss methods can be chosen when generating synthetic hydrographs. In this study, the SCS-CN method is selected.

3. Unit hydrograph method: One of several different unit hydrograph methods can be chosen when generating synthetic hydrographs. The SCS dimensionless Unit Hydrograph method is used.

4. Concentration Time: The SCS method of concentration time computation has been analyzed. 


\section{Results and discussions:-}

Digital elevation model and landforms of the study area:

The developed digital elevation model (DEM) for the study area is illustrated in Figure 3. Results indicated, in general, that the coastal plain slopes gently towards the north and increases towards the south. The studied area has elevations that vary from $\geq 0 \mathrm{~m}$ in the coastal area to $203 \mathrm{~m}$ above sea level to the south. Results showed also that study area includes eight landform units (Table 2 \& Figure 4) namely: coastal plain, sloping area, escarpment, coarse valley inner, coarse valley outer, low piedmont, moderately high piedmont and high piedmont. Wadi Umm Ashtan is dominated by high (61.8\%), moderately-high (18.5\%) and low piedmont (10\%), while wadi Umm ElRakham is dominated by low (29.9\%), high (26.8\%), and moderate piedmont (19\%).

Table 2:-Physiographic mapping units of wadi Umm Ashtan and wadi Umm El-Rakham

\begin{tabular}{|c|c|c|c|c|c|c|c|}
\hline \multirow{2}{*}{ Landscape } & \multirow{2}{*}{ Relief } & \multirow{2}{*}{ Lithology } & \multirow{2}{*}{ Landform } & \multicolumn{2}{|c|}{$\begin{array}{c}\text { Wadi Umm } \\
\text { Ashtan }\end{array}$} & \multicolumn{2}{|c|}{$\begin{array}{l}\text { Wadi Umm } \\
\text { El-Rakham }\end{array}$} \\
\hline & & & & $\begin{array}{l}\text { Area } \\
\left(\mathbf{K m}^{2}\right)\end{array}$ & $\%$ & $\begin{array}{l}\text { Area } \\
\left(\mathbf{K m}^{2}\right)\end{array}$ & $\%$ \\
\hline \multirow{2}{*}{ Coastal Plain } & Sea Beach & $\begin{array}{c}\text { Undifferentiated } \\
\text { Quaternary Deposits }\end{array}$ & Coastal Plain & 0.65 & 0.6 & 5.89 & 7.0 \\
\hline & Sand Sheet & Marmarica Formation & Sloping area & 1.66 & 1.6 & 4.77 & 5.7 \\
\hline \multirow{5}{*}{$\begin{array}{l}\text { Northern } \\
\text { Plateau }\end{array}$} & Plateau & $\begin{array}{c}\text { El Hagif Formation } \\
\text { Deposits }\end{array}$ & Escarpment & 1.68 & 1.6 & 3.7 & 4.4 \\
\hline & \multirow{2}{*}{$\begin{array}{l}\text { Coarse } \\
\text { Valley }\end{array}$} & \multirow{2}{*}{$\begin{array}{l}\text { El Hagif Formation } \\
\text { Deposits }\end{array}$} & Coarse Valley Inner & 2.32 & 2.2 & 2.27 & 2.7 \\
\hline & & & Coarse Valley, Outer & 3.95 & 3.7 & 3.71 & 4.4 \\
\hline & \multirow[b]{2}{*}{ Plateau } & \multirow{2}{*}{$\begin{array}{l}\text { El Hagif Formation } \\
\text { Deposits }\end{array}$} & Low Piedmont & 10.54 & 10.0 & 24.99 & 29.9 \\
\hline & & & $\begin{array}{l}\text { Moderately high } \\
\text { Piedmont }\end{array}$ & 19.58 & 18.5 & 15.9 & 19.0 \\
\hline $\begin{array}{l}\text { Southern } \\
\text { Plateau }\end{array}$ & Plateau & Marmarica Formation & High Piedmont & 65.46 & 61.8 & 22.47 & 26.8 \\
\hline \multicolumn{4}{|c|}{ Total Area } & 105.84 & 100 & 83.7 & 100 \\
\hline
\end{tabular}

\section{Soil studies:}

The soils of these units vary in their depth from shallow to moderately deep, except the coastal plain and coarse valley inner units which are deep soils (Table 3). The $\mathrm{pH}$ values are moderately alkaline (ranging from 7.85 to 8.0), while the salinity values vary from non-saline to moderately saline soils (EC from 1.6 to $7.5 \mathrm{dS} / \mathrm{m}$ ). The calcium carbonate is high (ranging from 21.8 to $32.0 \%$ ), however the gypsum and organic matter content are very low (Table 3 ). According to the physical and chemical characteristics, these soils are suitable for agriculture activities by cultivating some crops, e.g. wheat, barley and tomato in shallow and moderately deep units, however in coarse valley inner, the soils are suitable for cultivated with trees, e.g. fig, date palm, and olive (Figure 6). 


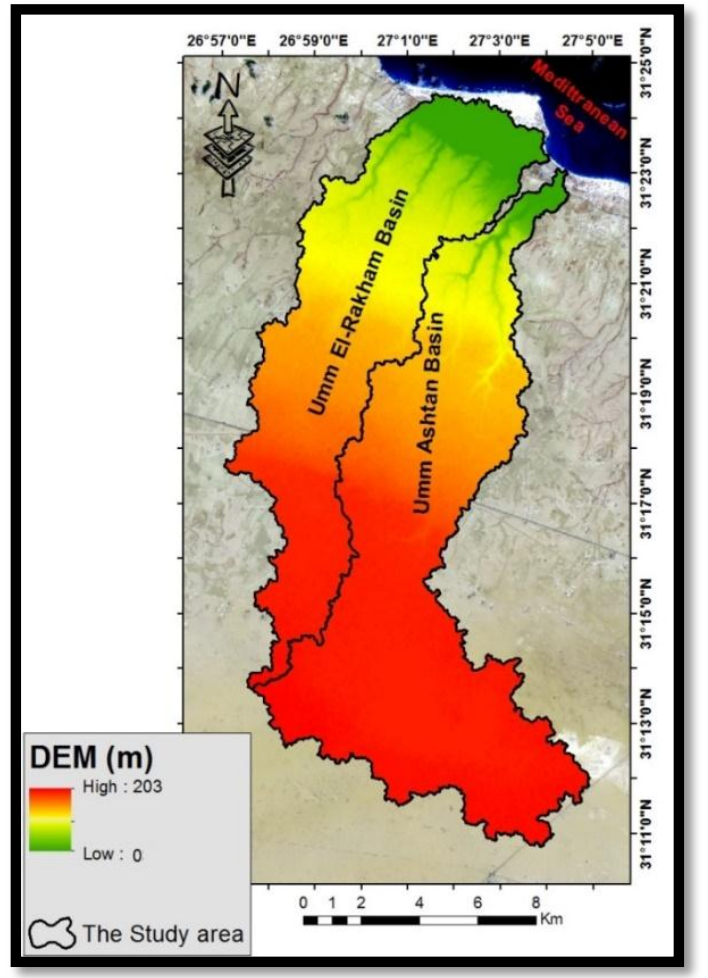

Figure 3:-Digital elevation model (DEM) of the study area.

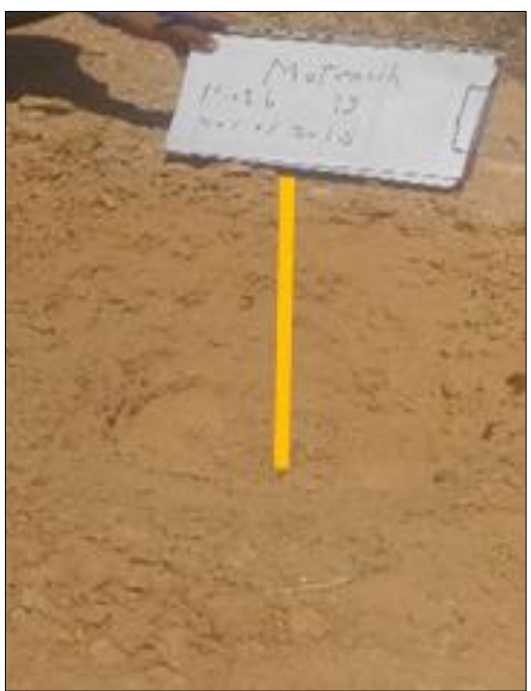

Figure 5:-Moderately deep soil profile in high pediment unit.

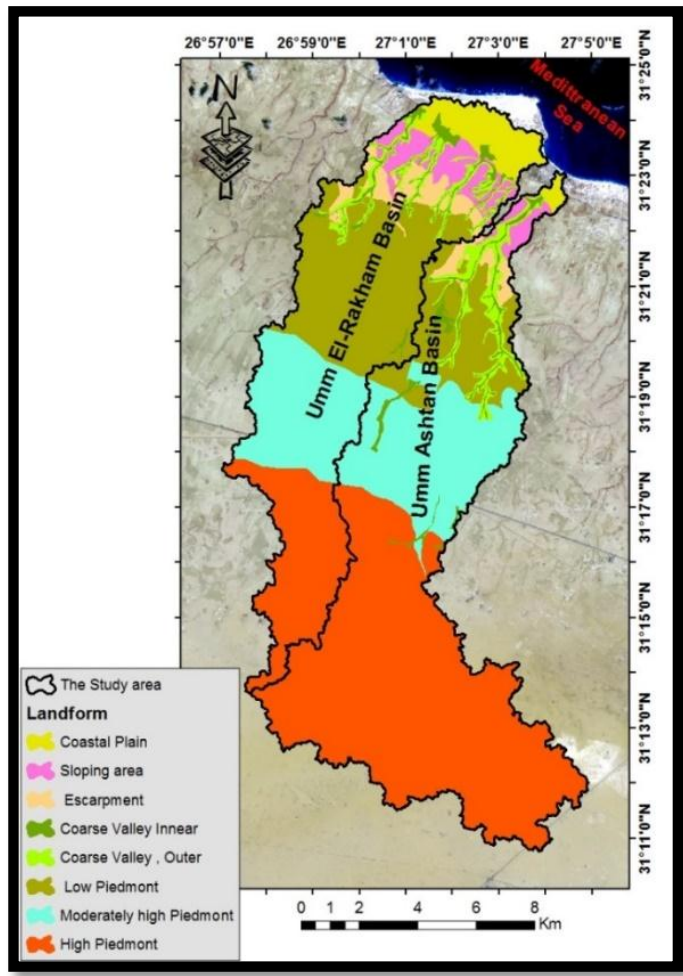

Figure 4:-Landform units of the of the study area.

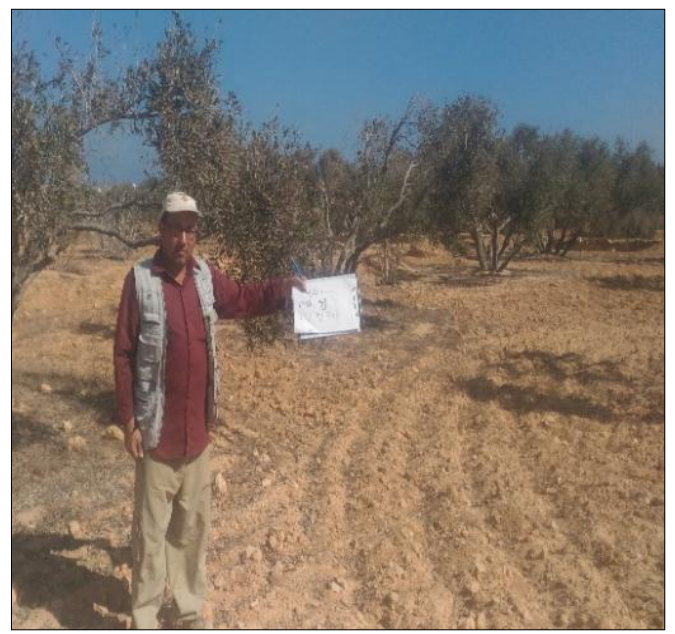

Figure 6:-Olive trees in deep soils coarse valley inner unit.

Table 3:-Soil texture and some chemical characteristics of the samples collected from soil profiles in the studied landforms.

\begin{tabular}{|c|c|c|c|c|c|c|c|c|}
\hline \multirow{2}{*}{ Landform } & $\begin{array}{c}\text { Profile } \\
\text { No. }\end{array}$ & $\begin{array}{c}\text { Depth } \\
(\mathbf{c m})\end{array}$ & $\mathbf{p H}$ & $\begin{array}{c}\text { EC } \\
\mathbf{d S} / \mathbf{m}\end{array}$ & $\begin{array}{c}\mathbf{C a C O}_{\mathbf{3}} \\
(\boldsymbol{\%})\end{array}$ & $\begin{array}{c}\text { Organic } \\
\text { Matter (\%) }\end{array}$ & $\begin{array}{c}\text { Gypsum } \\
(\boldsymbol{\%})\end{array}$ & Texture* $^{*}$ \\
\hline \multirow{2}{*}{ Coastal Plain } & 1 & 110 & 7.90 & 2.20 & 29.5 & 0.30 & 0.60 & SL \\
\cline { 2 - 9 } & 2 & 110 & 7.85 & 4.70 & 28.3 & 0.22 & 0.55 & SL \\
\cline { 2 - 9 } & 3 & 45 & 8.00 & 2.00 & 24.3 & 0.21 & 0.24 & SL \\
\hline \multirow{2}{*}{ Sloping Area } & 4 & 40 & 8.00 & 1.65 & 23.2 & 0.23 & 0.15 & SL \\
\cline { 2 - 8 } & 5 & 40 & 7.95 & 1.85 & 27.0 & 0.18 & 0.14 & LS \\
\hline
\end{tabular}




\begin{tabular}{|c|c|c|c|c|c|c|c|c|}
\hline & 6 & 40 & 7.95 & 2.30 & 23.8 & 0.14 & 0.16 & LS \\
\hline \multirow[t]{3}{*}{ Escarpment } & 7 & 30 & 7.85 & 2.14 & 21.8 & 0.27 & 0.17 & LS \\
\hline & 8 & 25 & 8.00 & 3.20 & 28.4 & 0.27 & 0.15 & LS \\
\hline & 9 & 60 & 7.90 & 1.60 & 28.4 & 0.20 & 0.18 & SL \\
\hline \multirow[t]{8}{*}{ Coarse Valley Inner } & 10 & 110 & 7.90 & 3.10 & 23.1 & 0.25 & 0.90 & SCL \\
\hline & 11 & 120 & 8.00 & 2.00 & 26.5 & 0.34 & 0.60 & SCL \\
\hline & 12 & 105 & 7.80 & 2.30 & 28.5 & 0.26 & 0.10 & SCL \\
\hline & 13 & 110 & 7.95 & 3.80 & 25.1 & 0.24 & 0.19 & SL \\
\hline & 14 & 110 & 7.95 & 2.50 & 27.5 & 0.28 & 1.40 & SCL \\
\hline & 15 & 110 & 7.90 & 2.00 & 27.5 & 0.23 & 0.65 & SCL \\
\hline & 16 & 110 & 7.90 & 2.10 & 26.5 & 0.23 & 1.00 & SL \\
\hline & 17 & 55 & 8.00 & 6.50 & 28.5 & 0.31 & 0.17 & SCL \\
\hline \multirow[t]{5}{*}{ Coarse Valley Outer } & 18 & 30 & 7.90 & 4.25 & 28.4 & 0.26 & 1.40 & SCL \\
\hline & 19 & 60 & 7.70 & 3.40 & 22.1 & 0.20 & 0.17 & SL \\
\hline & 20 & 55 & 8.00 & 2.80 & 29.1 & 0.22 & 0.15 & SCL \\
\hline & 21 & 30 & 7.80 & 4.60 & 24.1 & 0.27 & 0.17 & LS \\
\hline & 22 & 20 & 7.95 & 2.57 & 28.4 & 0.30 & 0.12 & SCL \\
\hline \multirow[t]{6}{*}{ Low Piedmont } & 23 & 60 & 8.00 & 3.27 & 25.3 & 0.30 & 0.85 & SCL \\
\hline & 24 & 40 & 7.90 & 3.10 & 25.7 & 0.23 & 0.17 & SL \\
\hline & 25 & 60 & 7.90 & 2.50 & 24.0 & 0.26 & 0.18 & SCL \\
\hline & 26 & 40 & 8.00 & 4.50 & 28.4 & 0.20 & 0.20 & SCL \\
\hline & 27 & 30 & 7.95 & 1.80 & 25.7 & 0.28 & 1.10 & $\mathrm{LS}$ \\
\hline & 28 & 40 & 8.00 & 2.65 & 23.2 & 0.25 & 1.00 & SL \\
\hline \multirow{8}{*}{$\begin{array}{l}\text { Moderately High } \\
\text { Piedmont }\end{array}$} & 29 & 55 & 7.90 & 6.40 & 25.0 & 0.24 & 1.30 & SCL \\
\hline & 30 & 45 & 8.00 & 3.70 & 28.0 & 0.22 & 0.15 & SCL \\
\hline & 31 & 55 & 7.90 & 2.80 & 26.0 & 0.25 & 0.12 & SL \\
\hline & 32 & 55 & 7.90 & 6.50 & 26.7 & 0.22 & 0.20 & SCL \\
\hline & 33 & 45 & 7.90 & 3.80 & 26.5 & 0.13 & 0.15 & SCL \\
\hline & 34 & 20 & 7.90 & 3.50 & 25.7 & 0.21 & 0.17 & SCL \\
\hline & 35 & 40 & 8.00 & 2.55 & 25.0 & 0.23 & 0.50 & $\mathrm{LS}$ \\
\hline & 36 & 80 & 7.95 & 3.50 & 25.3 & 0.25 & 1.50 & SCL \\
\hline \multirow[t]{14}{*}{ High Piedmont } & 37 & 40 & 7.90 & 2.90 & 24.6 & 0.30 & 1.40 & SL \\
\hline & 38 & 45 & 7.70 & 3.00 & 25.1 & 0.16 & 1.20 & SL \\
\hline & 39 & 60 & 8.00 & 2.80 & 22.5 & 0.15 & 0.50 & LS \\
\hline & 40 & 55 & 8.00 & 2.65 & 25.3 & 0.22 & 0.13 & SL \\
\hline & 41 & 35 & 7.95 & 4.00 & 20.7 & 0.13 & 0.16 & LS \\
\hline & 42 & 20 & 7.95 & 4.50 & 24.4 & 0.27 & 0.13 & SL \\
\hline & 43 & 30 & 7.90 & 3.37 & 23.8 & 0.29 & 0.12 & SL \\
\hline & 44 & 30 & 8.00 & 7.50 & 28.6 & 0.25 & 0.18 & LS \\
\hline & 45 & 20 & 8.00 & 4.40 & 29.3 & 0.16 & 0.13 & SCL \\
\hline & 46 & 40 & 8.10 & 3.50 & 31.1 & 0.23 & 0.21 & SL \\
\hline & 47 & 30 & 7.95 & 2.52 & 29.3 & 0.26 & 0.15 & SL \\
\hline & 48 & 15 & 7.95 & 3.38 & 32.0 & 0.23 & 0.13 & $\mathrm{SL}$ \\
\hline & 49 & 150 & 7.90 & 3.10 & 29.3 & 0.25 & 1.10 & SL \\
\hline & 50 & 55 & 8.00 & 3.20 & 29.2 & 0.22 & 1.40 & SL \\
\hline
\end{tabular}

* S1: Sandy Loam

LS: Loamy Sand

SCL: Sandy Clay Loam

Morphometric parameters of the study basins:

Basin boundaries and drainage lines of the study area (Figure 7) were extracted by using the digital elevation model (DEM, $12.5 \mathrm{~m}$ resolution) and the WMS 10.0 software. Also, the morphometric and geometric parameters (e.g. area, basin slope, basin length, maximum stream length, centroid stream distance, perimeter, shape factor and sinuosity factor) were automatically calculated for each basin (Table 4).

Results showed that Umm Ashtan basin is characterized by larger basin area $\left(105.8 \mathrm{~km}^{2}\right)$, basin length of $34.3 \mathrm{~km}$, perimeter of $119.4 \mathrm{~km}$, and gentle slope $(0.024 \mathrm{~m} / \mathrm{m})$, while Umm El-Rakham basin is characterized by smaller basin area $\left(83.7 \mathrm{~km}^{2}\right)$, basin length of $32.7 \mathrm{~km}$, perimeter of $93.7 \mathrm{~km}$, and gentle slope $(0.033 \mathrm{~m} / \mathrm{m})$. Also, Umm Ashtan basin has higher maximum stream length and centroid stream distance and lower shape and sinuosity factors 
than Umm El-Rakham basin. These results indicate that, Um Ashtan basin has more rainwater harvesting potentiality than the other basin. The obtained results agreed with those of Morisawa (1959) and Verstappen (1983), who stated that basin area is identified as the most important of all the morphometric parameters controlling the catchment runoff pattern. This is because, the larger the size of the basin, the greater the amount of rain it intercepts and the higher the peak discharge that result. The results agreed also with those reported by Gregory and Walling (1973) and Jain and Sinha (2003), who indicated that the basin area is highly correlated with some of the other catchment hydro-morphometric characteristics, such as basin length which influence runoff.

Table 4:-Some morphometric parameters of the study basins.

\begin{tabular}{|c|c|c|c|c|c|c|c|c|}
\hline $\begin{array}{c}\text { Basin } \\
\text { name }\end{array}$ & $\begin{array}{c}\text { Area (A) } \\
\left(\mathbf{k m}^{2}\right)\end{array}$ & $\begin{array}{c}\text { Basin } \\
\mathbf{s l o p e} \\
(\mathbf{m} / \mathbf{m})\end{array}$ & $\begin{array}{c}\text { Basin } \\
\text { Length } \\
(\mathbf{m})\end{array}$ & $\begin{array}{c}\text { Max. } \\
\text { Stream } \\
\text { Length } \\
(\mathbf{m})\end{array}$ & $\begin{array}{c}\text { Centroid } \\
\text { Stream } \\
\text { Distance } \\
(\mathbf{m})\end{array}$ & $\begin{array}{c}\text { Perimeter } \\
(\mathbf{m})\end{array}$ & $\begin{array}{c}\text { Shape } \\
\mathbf{F a c t o r} \\
\left(\mathbf{m}^{2} / \mathbf{m}^{2}\right)\end{array}$ & $\begin{array}{c}\text { Sinuosity } \\
\text { Factor } \\
(\mathbf{M S L} / \mathbf{L})\end{array}$ \\
\hline $\begin{array}{c}\text { Umm } \\
\text { Ashtan }\end{array}$ & 105.8 & 0.024 & 34353.9 & 30543.7 & 17187.5 & 119423.7 & 5.01 & 1.43 \\
\hline $\begin{array}{c}\text { Umm El- } \\
\text { Rakham }\end{array}$ & 83.7 & 0.033 & 32683.7 & 27345.8 & 14823.2 & 93686.0 & 5.71 & 1.44 \\
\hline
\end{tabular}

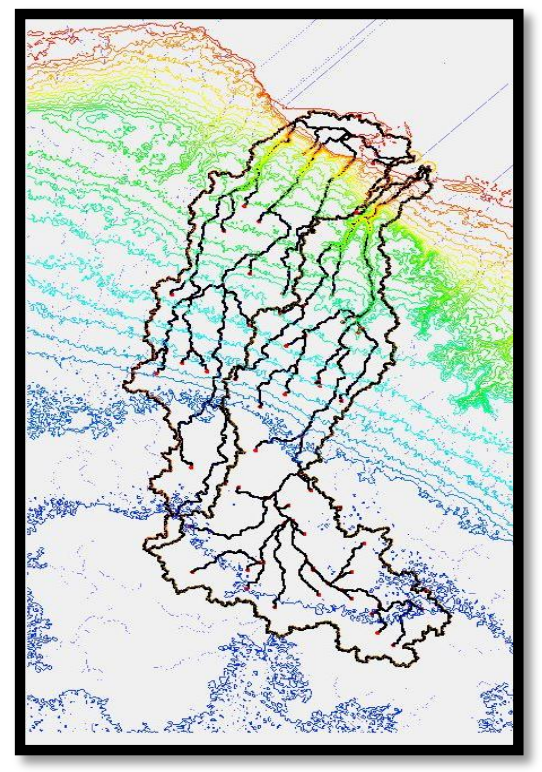

(a)

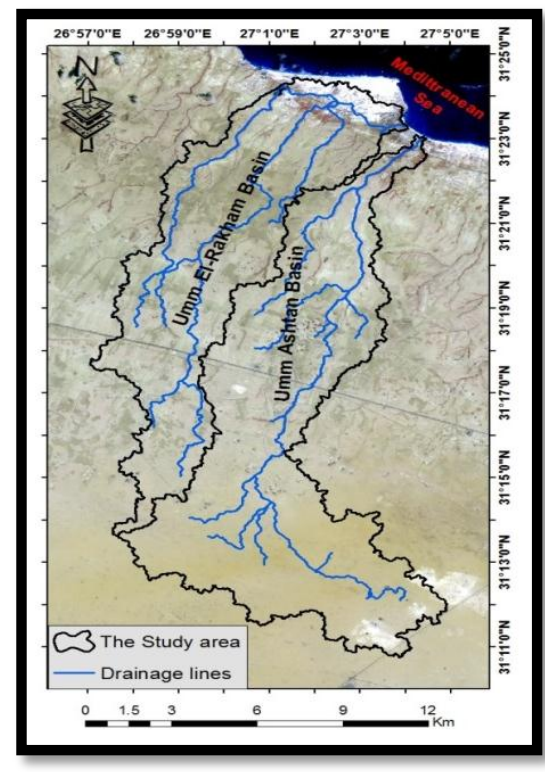

(b)

Figure 7:-The drainage lines and basin boundaries of the study area produced from WMS model.

\section{Land use and hydrologic soil maps of the study area:}

Based on field observation and the supervised maximum likelihood classification of Setinal-2 satellite image $(10 \mathrm{~m}$ resolution), results showed that there are three types of land use/land cover in the studied basins, namely: Agricultural land, barren land and urban (Figure 8a). The land use/land cover types represent 16.4, 83.59 and $0.21 \%$ of Umm Ashatan basin and 34.0, 64.3 and 1.7\% of Umm Al-Rakham basin, respectively.

In order to determine the hydrologic soil groups and to develop classification map (Fig. 8b), soil texture classification of the study area was done from the mechanical analysis of soil samples. Soil types were simplified and reclassified using kriging interpolation ig ArcGIS Desktop 10.4.1. The soil texture classifications were reclassified to SCS Soil Types A, B, C and D depending on soil infiltration (USDA, U.D. 1986). The infiltration rates decrease from soil group A to $\mathrm{D}$, which is inversely related to the rainwater harvesting (RWH) capabilities for the same group and the higher the infiltration capability of the soil is the lower the RWH potentialities, and vice versa (Elewa et al., 2013).

The hydrologic soil groups (HSG) in the study basins included only two types, namely: 
1. Soil group (A): has loamy sand (SL) and sandy loam (LS) textural classes and is characterized with the highest infiltration rate. This group represents 30,75 , and $50 \%$ of agricultural land, barren land, and urban land use/land cover types of Umm Ashtan basin, and represent 40, 60, and 90\% for the same respective types of Umm ElRakham basin.

2. Soil group (C): has sandy clay loam (SCL) textural class and is characterized with low infiltration rate. This group represents 70,25 , and $50 \%$ of agricultural land, barren land, and urban land use/land cover types of Umm Ashtan basin, and represent 60, 40, and 10\% for the same respective types of Umm El-Rakham basin.

The Soil Conservation Service Curve Number (SCS-CN) method, which was run inside the WMS v10.0, was used to calculate surface runoff and to define the infiltration characteristics of the two basins. Results showed that, the allover average curve number $(\mathrm{CN})$ values using different combinations of land use and HSG for Umm Ashtan is 73.8 and for Umm El-Rakham watersheds is 76.15 (Tables 5 and 6).

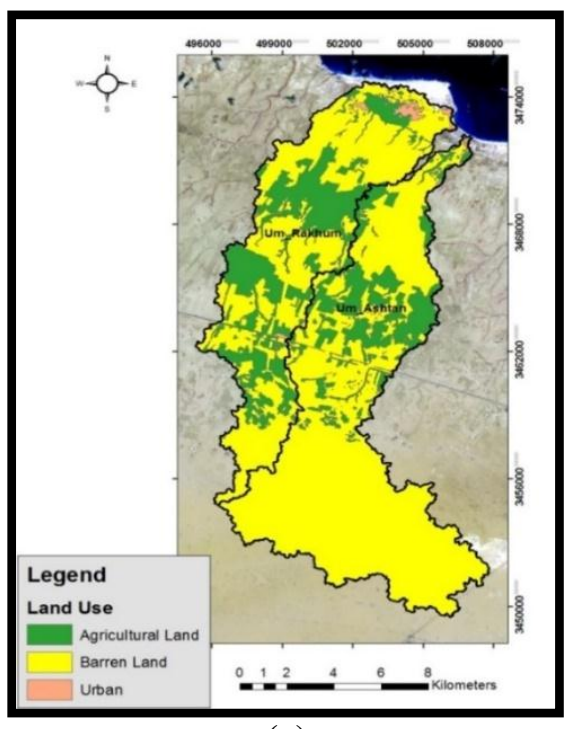

(a)

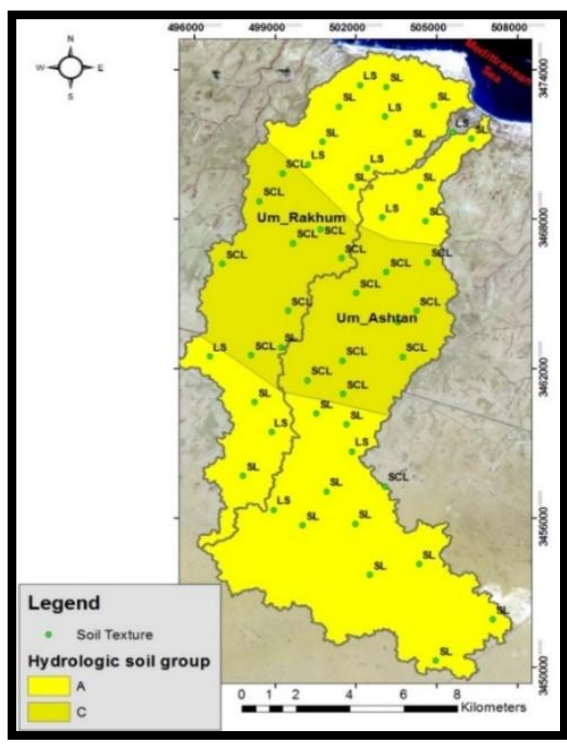

(b)

Figure 8:-Land use map (a) and hydrologic soil map (b) of study area.

Table 5:-Land use/land cover types and areas, hydrologic soil groups, and average Curve Number values for Umm Ashtan Basin.

\begin{tabular}{|c|c|c|c|c|c|c|c|c|}
\hline \multirow[t]{2}{*}{ Land use/ land cover } & \multicolumn{2}{|c|}{ Area } & \multicolumn{2}{|c|}{ Soil group (A) } & \multicolumn{2}{|c|}{ Soil group (C) } & \multirow{2}{*}{$\begin{array}{c}\text { Average } \\
\text { CN }\end{array}$} & \multirow{2}{*}{$\begin{array}{c}\text { Allover } \\
\text { Average } \\
\text { CN }\end{array}$} \\
\hline & $\left(\mathrm{km}^{2}\right)$ & $\%$ & $\%$ & $\mathrm{CN}$ & $\%$ & $\mathrm{CN}$ & & \\
\hline Agriculture land & 17.34 & 16.39 & 30 & 67 & 70 & 85 & 79.6 & 73.8 \\
\hline Barren land & 88.23 & 83.40 & 75 & 68 & 25 & 86 & 72.5 & \\
\hline Urban & 0.23 & 0.21 & 50 & 77 & 50 & 90 & 83.5 & \\
\hline Total & 105.8 & 100.0 & & & & & & \\
\hline
\end{tabular}

Table 6:-Land use/land cover types and areas, hydrologic soil groups, and average Curve Number values for Umm El-Rakham Basin.

\begin{tabular}{|l|c|c|c|c|c|c|c|c|}
\hline \multirow{2}{*}{ Land use/ land cover } & \multicolumn{2}{|c|}{ Area } & \multicolumn{2}{c|}{ Soil group (A) } & \multicolumn{2}{c|}{ Soil group (C) } & $\begin{array}{c}\text { Average } \\
\text { CN }\end{array}$ & $\begin{array}{c}\text { Allover } \\
\text { Average } \\
\end{array}$ \\
\cline { 2 - 7 } & $\left(\mathrm{km}^{2}\right)$ & $\%$ & $\%$ & $\mathrm{CN}$ & $\%$ & $\mathrm{CN}$ & & CN \\
\hline Agriculture land & 28.44 & 33.98 & 40 & 67 & 60 & 85 & 77.8 & \multirow{2}{*}{76.15} \\
\hline Barren land & 53.83 & 64.32 & 60 & 68 & 40 & 86 & 75.2 & \\
\hline Urban & 1.43 & 1.70 & 90 & 77 & 10 & 90 & 78.3 & \\
\hline Total & 83.70 & 100.0 & & & & & & \\
\hline
\end{tabular}




\section{Annual runoff and infiltration volumes for the study area:}

For basins where monitoring activity doesn't exist, the SCS-CN method can be used to estimate the depth of direct runoff from the rainfall depth, providing an index describing runoff response characteristics. To describe these curves mathematically, the model uses the water balance equation and two hypothetical equations such as the proportional equality between the ratio of actual retention $(\mathrm{F})$ to potential maximum retention $(\mathrm{S})$, and the ratio of actual runoff $(\mathrm{Q})$ to potential maximum runoff $(\mathrm{P})$ \{expressed as rainfall $(\mathrm{P})$ minus initial abstraction (Ia) \}. The governing equations are expressed as follows:

Water balance equation:

The proportional relationship:

$$
P=I a+F+Q
$$

$$
\frac{F}{S}=\frac{Q}{(P-I a)}
$$

for simplification, the following condition is used:

Where:

$$
I a=0.2 S
$$

$$
\begin{array}{ll}
\mathrm{P} & =\text { accumulated rainfall depth (inch) } \\
\mathrm{Ia} & \text { = initial abstraction } \\
\mathrm{F} & \text { = cumulative infiltration excluding Ia (i.e. actual retention, inch) } \\
\mathrm{Q} & =\text { excess rainfall or direct runoff volume (direct runoff depth, inch) } \\
\mathrm{S} & \text { = maximum potential abstraction of water by soil, in inch } \\
0.2 & =\text { a standard constant value }
\end{array}
$$

After runoff has started, all additional rainfall becomes either runoff or actual retention. According to Bedient \& Huber (1992), combining equations (1), (2) and (3) gives an expression for Q:

Eq. (4) is valid for $\mathrm{P} \geq \mathrm{Ia}, \mathrm{Q}=0$.

$$
Q=\frac{(P-I a)^{2}}{(P-I a)+S}=\frac{(P-0.2 S)^{2}}{(P)+0.8 S}
$$

The equation for the maximum potential retention $(\mathrm{S})$ is defined based on curve number $(\mathrm{CN})$ as:

$$
S=\frac{1000}{C N}-10
$$

The runoff water and infiltration volumes are calculated as follows:

$$
\text { Volume of runoff water }\left(\mathrm{m}^{3}\right)=\mathrm{A} \times \mathrm{Q}
$$

$$
\text { Infiltration Volume }\left(\mathrm{m}^{3}\right)=\mathrm{F} \times \mathrm{A} \times \text { area exposed (\%) (7) }
$$

where A: Basin area

Results indicated that, the calculated annual runoff water volume is $66150.0 \mathrm{~m}^{3}$ for Umm Ashtan watershed and $49896.7 \mathrm{~m}^{3}$ for Umm El-Rakham watershed. However, the annual infiltration volume is $41398.0 \mathrm{~m}^{3}$ for Umm Ashtan watershed and $26450.6 \mathrm{~m}^{3}$ for Umm El-Rakham watershed (Table 7). Results showed that Umm Ashtan basin has 49.7 and $112.3 \%$ higher annual runoff and infiltration volumes than those of Umm El-Rakham basin. Since infiltration rates decreases from soil group A to $\mathrm{D}$, which is inversely related to the rainwater harvesting (RWH) capabilities for the same group and the higher the infiltration capability of the soil is the lower the RWH potentialities, and vice versa (Elewa et al., 2013), it could be concluded from the results that the net RWH potentiality for Umm El-Rakham basin is about $26 \%$ higher than Umm Astan basin.

Table 7:-Annual runoff water and infiltration volumes in the studied basins.

\begin{tabular}{|c|c|c|c|c|c|c|c|c|}
\hline Basin & $\begin{array}{c}\text { Average } \\
\text { Annual } \\
\text { rainfall } \\
\mathrm{P}(\text { inch) }\end{array}$ & $\begin{array}{c}\text { Area } \\
\text { exposed } \\
\%\end{array}$ & $\begin{array}{c}\mathrm{S} \\
\text { (inch) }\end{array}$ & $\begin{array}{c}\text { Ia } \\
\text { (inch) }\end{array}$ & $\begin{array}{c}\text { Direct } \\
\text { runoff } \\
\mathrm{Q} \text { (inch) }\end{array}$ & $\begin{array}{c}\text { Actual } \\
\text { retention F } \\
\text { (inch) }\end{array}$ & $\begin{array}{c}\text { Runoff } \\
\text { Water } \\
\text { volume } \\
\left(\mathrm{m}^{3}\right)\end{array}$ & $\begin{array}{c}\text { Infiltration } \\
\text { Volume } \\
\left(\mathrm{m}^{3}\right)\end{array}$ \\
\hline $\begin{array}{c}\text { Umm } \\
\text { Ashtan }\end{array}$ & 5.001 & 83.6 & 3.16 & 0.632 & 2.534 & 1.842 & 66150.0 & 41398.0 \\
\hline $\begin{array}{c}\text { Umm El- } \\
\text { Rakham }\end{array}$ & 5.001 & 64.0 & 3.55 & 0.71 & 2.347 & 1.944 & 49896.7 & 26450.6 \\
\hline
\end{tabular}




\section{Surface runoff water volume for different returned periods:}

Annual rainfall data obtained from Matrouh station for a time period about 15 years (2001-2015) were analyzed in order to determine the design rainfall amount. Statistical analytical tests concerning the rainfall values have been carried out using HYFRAN PLUS software. The designed precipitation for estimating the rainfall intensity values at different returned periods $(2,5,10,25,50$ and 100 years) based on the assumption of Generalized Extreme Value (GEV) distribution maximum likelihood, was computed. The distribution gave the best fit for the collected data and the probability of occurrence curve for the observed and predicted data was derived (Figure 9). The maximum annual values of daily rainfall for the selected observation period (2001-2015) were used to determine long-term discharge series (Table 8). The HEC-1 (Hydrologic Engineering Center's Hydrologic Modeling System; Feldman, 1995) run within WMS v10.0 software, was applied after introducing the input data, e.g. curve number for each basin, rainfall intensity for each return period and the concentration time by SCS method for each basin. Results showed that, the SCS-24 storm type II represents the best distribution to simulate the rainfall-runoff event for various return intervals, because it is the most similar to the observed instantaneous rainfall during the storm event.

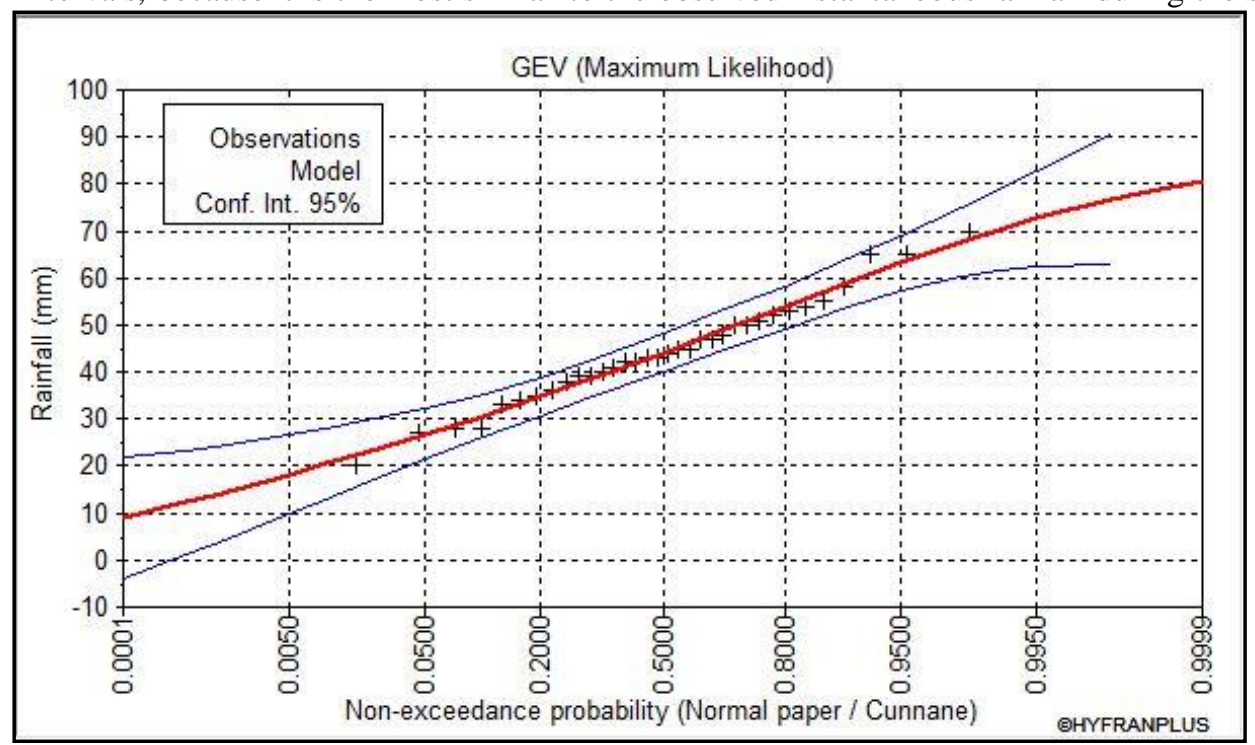

Figure 9:-Probability of occurrence of annual rainfall data.

Table 8:-Rainfall intensity values for different return periods.

\begin{tabular}{|c|c|}
\hline Return period (years) & Rainfall depth (mm) \\
\hline 5 & 36 \\
\hline 10 & 49 \\
\hline 25 & 69 \\
\hline 50 & 87 \\
\hline 100 & 108 \\
\hline
\end{tabular}

The resulted runoff hydrographs of the storm event for the two watersheds are shown in Figure 10. 


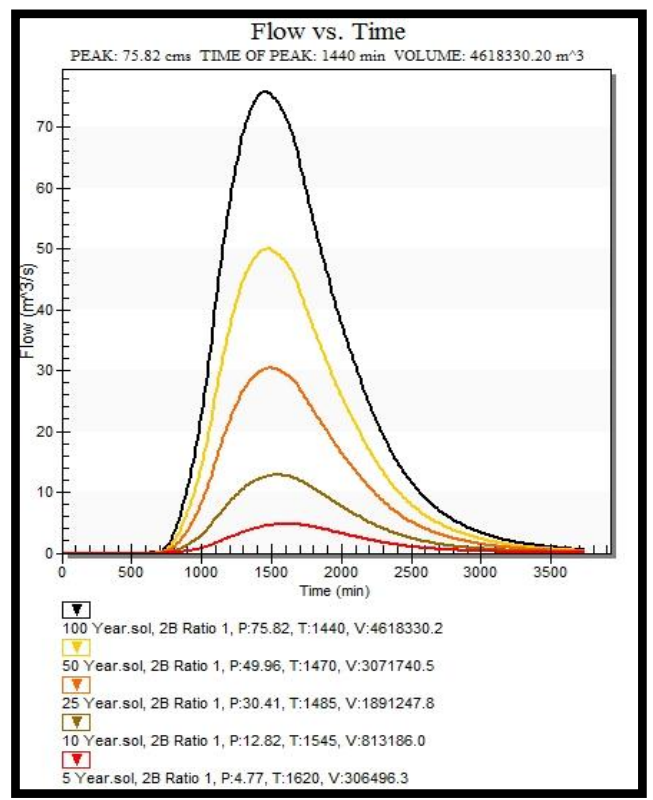

(a)

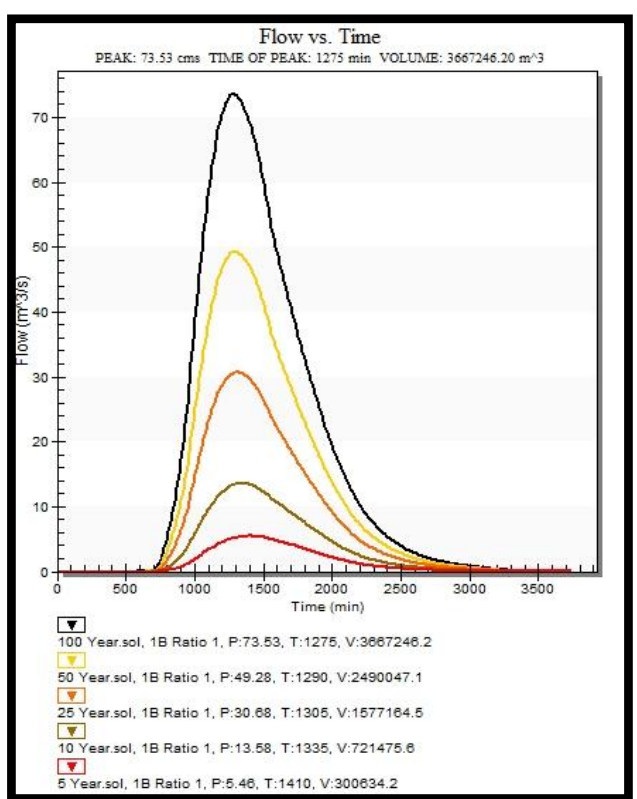

(b)

Figure 10:-The predicted rainfall-runoff values of different return periods for Umm El-Rakham (a) and Umm Ashtan (b) basins.

Results indicated for Umm Ashtan basin that, the peak discharge values were 73.53, 49.28, 30.68, 13.58 , and 5.46 $\mathrm{m}^{3} / \mathrm{s}$ for the 100-, 50-, 25-, 10-, and 5-year return periods, respectively. As for Umm El-Rakham basin, the peak discharge values were $75.82,49.96,30.41,12.82$, and $4.77 \mathrm{~m}^{3} / \mathrm{s}$ for the same respective returning periods (Tables 9 and 10). Results showed also that, the runoff in the two watersheds, predicted by the SCS-CN model, increases gradually as rainfall increases.

The runoff volumes for Umm Astan basin were of the 100 year-return-period is $3667.25 \times 10^{3} \mathrm{~m}^{3}, 2490.05 \times 10^{3} \mathrm{~m}^{3}$, $1577.16 \times 10^{3} \mathrm{~m}^{3}, 721.47 \times 10^{3} \mathrm{~m}^{3}$, and $300.63 \times 10^{3} \mathrm{~m}^{3}$ for the 100-, 50-, 25-, 10-, and 5-year return periods, respectively. While for Umm El-Rakham basin the runoff volumes were $4618.33 \times 10^{3} \mathrm{~m}^{3}, 3071.74 \times 10^{3} \mathrm{~m}^{3}$, $1891.25 \times 10^{3} \mathrm{~m}^{3}, 813.18 \times 10^{3} \mathrm{~m}^{3}$, and $306.49 \times 10^{3} \mathrm{~m}^{3}$ for the same respective returning periods (Tables 9 and 10 ).

Table 9:-Rainfall-Runoff data of Umm Ashtan basin.

\begin{tabular}{|c|c|c|c|c|}
\hline $\begin{array}{c}\text { Return Period } \\
\text { (years) }\end{array}$ & $\begin{array}{c}\text { Rainfall Intensity } \\
\mathrm{I}(\mathrm{mm})\end{array}$ & $\begin{array}{c}\text { Peak Discharge } \\
\mathrm{Q}\left(\mathrm{m}^{3} / \mathrm{sec}\right)\end{array}$ & $\begin{array}{c}\text { Peak Time } \\
(\mathrm{min})\end{array}$ & $\begin{array}{c}\text { Runoff } \\
\text { Water volume }\left(\mathrm{m}^{3}\right)\end{array}$ \\
\hline 5 & 36 & 5.46 & 1410 & 300634.2 \\
\hline 10 & 49 & 13.58 & 1335 & 721475.6 \\
\hline 25 & 69 & 30.68 & 1305 & 1577164.5 \\
\hline 50 & 87 & 49.28 & 1280 & 2490047.1 \\
\hline 100 & 108 & 73.53 & 1275 & 3667246.2 \\
\hline
\end{tabular}

Table 10:-Rainfall-Runoff data of Umm El-Rakham basin.

\begin{tabular}{|c|c|c|c|c|}
\hline $\begin{array}{c}\text { Return Period } \\
(\text { years })\end{array}$ & $\begin{array}{c}\text { Rain Intensity } \\
\mathrm{I}(\mathrm{mm})\end{array}$ & $\begin{array}{c}\text { Peak Discharge } \\
\mathrm{Q}\left(\mathrm{m}^{3} / \mathrm{sec}\right)\end{array}$ & $\begin{array}{c}\text { Peak Time } \\
(\mathrm{min})\end{array}$ & $\begin{array}{c}\text { Runoff } \\
\text { Water volume }\left(\mathrm{m}^{3}\right)\end{array}$ \\
\hline 5 & 36 & 4.77 & 1620 & 306496.3 \\
\hline 10 & 49 & 12.82 & 1545 & 813186.0 \\
\hline 25 & 69 & 30.41 & 1485 & 1891247.8 \\
\hline 50 & 87 & 49.96 & 1470 & 3071740.5 \\
\hline 100 & 108 & 75.82 & 1440 & 4618330.2 \\
\hline
\end{tabular}




\section{Conclusions:-}

From the obtained results, it could be concluded that:

1. According to the soil texture and chemical properties, the two basins are suitable for growing some field crops, e.g. wheat, barley and tomato in shallow and moderately deep units, and horticulture trees, e.g. fig, date palm and olive, in the coarse valley inner.

2. The two basins (Umm Ashtan and Umm El-Rakham) can be recommended to have priority for rainwater harvesting with agriculture potential benefits within the Northwestern coast of Egypt.

3. The research results prove the successful employment of a new methodology based on WMS, HEC-1, and DEM which lead to a good estimation of surface runoff .

\section{References:-}

1. Abdel-Kader, F.H., and FitzSimon, J. (2002): Participatory Land and Water Management in Dryland Agropastoral Areas. NW Coast of Egypt. Final Report, Department of Soil and Water Sciences, Faculty of Agriculture, Univ. of Alexandria, Egypt.

2. Bedient, P.B. and Huber, W.C. (1992): Hydrology and Floodplain Analysis. Massachusetts: Addison-Wesley Publishing Company.

3. C.L.A.C. (2015): Central Laboratory for Agricultural Climate (CLAC) website. http://www.calc.edu.eg.

4. DRC Staff. (2015): Integrated Agriculture Development of Northwestern coastal wadies. Annual report. Desert Research Center publications.

5. El-Hames, A.S. (2012): An empirical method for peak discharge prediction in ungauged arid and semi-arid region catchments based on morphological parameters and SCS curve. Journal of Hydrology. 456-457.

6. El-Shazely, E. M.; Abdel Hady, M. A. and El-Ghawaby. M. A. (1975): Geologic interpretation of LANDSAT satellite images for west Nile Delta area, Remote sensing research project. Academic of scientific research and tecknology, Cairo, Egypt.

7. Elewa, H.H., E.M. Ramadan, A.A. El-Feel, E.A. Abu El Ella, and A.M. Nosair. (2013): Runoff Water Harvesting Optimization by Using RS, GIS and Watershed Modeling in Wadi El-Arish, Sinai. International Journal of Engineering Research \& Technology (IJERT). 2 (12): 1635-1648.

8. EMRL. (2015): Environmental Modeling Research Laboratory. Watershed modeling system (WMS) version 10.0 tutorial. Utah: Brigham Young University.

9. EMSI. Watershed Modeling System (WMS). (2018): Available from Environmental Modeling Systems Incorporated (EMSI). http://www.ems-i.com/WMS/WMS_Overview/wms_overview.html.

10. ESRI. (2014): Arc Map version 10.4.1 User Manual. ESRI, 380 New York Street, Redlands, California, 923738100, USA.

11. FAO. (1970): Pre investment survey of the northwestern coastal region. ESE : SF/UAR 49.

12. Feldman, A.D. (1995): HEC-1 flood hydrograph package. In: Singh VP, editor. Computer models of watershed hydrology. Highlands Ranch, Colorado: Water Resources Publications.

13. Gregory, K.J., and D.E. Walling. (1973): Drainage Basin Form and Process: A Geomorphological Approach, Edward Arnold, London, 456 pp.

14. Jain, V., and R. Sinha. (2003): Evaluation of Geomorphic Control on Flood Hazard Through Geomorphic Instantaneous Unit Hydrograph. Current Science. 85(11): 26-32.

15. Morisawa, M.E. (1959): Relation of morphometric properties to runoff in the Little Mill Creek, Ohio Drainage Basin, (Columbia University, Dept. of Geol.) Technical Report, 17, office of Naval Research, Project NR 389042 .

16. Moustafa, A.T.A. (1994): Agriculture Development in the Northwestern Zones of Egypt. In: FAO. 1994. Water Harvesting for Improved Agricultural Production: Proceedings of the FAO Expert Consultation, Cairo, Egypt 21-25 November 1993. FAO Water Reports 3. Rome.

17. NHE-4. (1993): National Engineering Handbook, Supplement A, Section 4- hydrology. Soil Conservation Service, USDA, Washington, DC.

18. Rajesh, R.S. (2007): Land Use Land Cover Change Projection for use in Municipal Water Resource Planning in the Saugahatchee Watershed. Ph.D. Thesis. Faculty of Auburn University, Alabama, USA.

19. Richards, L.A. (1954): Diagnosis and Improvement of Saline and Alkali Soils. U.S.D.A. Hand Book No. 60.

20. Sayed, A. (2013): Evaluation of the Land Resources for Agriculture Development - Case Study: El-Hammam Canal extension NW Coast of Egypt. PhD Thesis. Hamburg University.

21. Shata, A. (1971): 'The geomorphology, pedology and hydrogeology of the Mediterranean coastal desert of U.A.R.' Symposium on the geology of Libya, Tripoli, Libya, pp. 431-446. 
22. UNESCO (1977): Map of the World Distribution of Arid Regions, MAB Technical Notes, 7.

23. USACE (1994): Flood-Runoff Analysis. Engineering Manual, 110-2-1417.Washington.

24. USDA (2004): Soil Laboratory methods. Soil Survey Investigation. Report No 42 version 4 .0 November 2004.

25. USDA, U.D. (1986): Urban hydrology for small watersheds. Technical Release, (TR-55), USDA Soil Conservation Service, Washington, DC.

26. Verheye, W. and D. de la Rosa. (2005): Mediterranean Soils, in Land Use and Land Cover, from Encyclopedia of Life Support Systems (EOLSS), Developed under the Auspices of the UNESCO, Eolss Publishers, Oxford, UK. (http://www.eolss.net).

27. Verstappen, H. (1983): The applied geomorphology, International Institute for Aerial Survey and Earth Science (I.T.C.), Enschede, Netherlands, Amsterdam, Oxford, New York.

28. Walkley, A. and Black. (1947): A critical examination of a rapid method for determining organic carbon in soils. Soil Sci. 63:251-264.

29. Xiao, B., Q.H. Wang, J. Fan, F.P. Han and Q.H. Dai. (2011): Application of the SCS-CN model to runoff estimation in a small watershed with high spatial heterogeneity. Pedosphere. 21 (6) 738-749.

30. Xiaoyong Zhan and Min-Lang Huang (2004): Arc CN Runoff: an Arc GIS tool for generating curve number and runoff maps, Environmental Modelling \& Software. (19) $875-879$.

31. Zinck, J.A. (1988): Geomorphology and Soils. Internal Publ., ITC., Enschede, The Netherlands. 